\title{
Conservation Design for Traditional Agricultural Villages: A Case Study of Shirakawa-go and Gokayama in Japan*
}

\author{
Nobu Kuroda \\ World Heritage Studies, Faculty of Art and Design, University of Tsukuba, Ibaraki, Japan \\ Email: kuroda@heritage.tsukuba.ac.jp
}

\begin{abstract}
Agricultural villages in Japan are declining and disappearing rapidly. When an agricultural village goes extinct, its tradition and culture die as well. Conserving agricultural villages as cultural heritage sites is one way of preserving them for the future. Agricultural villages can be influenced by the economic and social situation of a country. To safeguard both tangible and intangible cultural traditions, the way that we interpret them is important. Re-designing elements of the landscape may be necessary for conservation, but it may change the natural environment of a village. This paper aims to discuss conservation design in agricultural villages through a case study of the historic villages of Shirakawa-go and Gokayama, which are World Heritage Sites. In Shirakawa mura, there are regulations for the design of landscape elements. Tangible elements are controlled by regulations and guidelines. Gassho-style houses are crucial elements of the design, and each element has a relationship with everyday activities such as agriculture and sericulture. In modern times, relationships with nature have become tenuous, and activity in forest areas has declined. To pass on the traditions and culture of these villages to the next generation, it is important to create new links between each element. An agricultural village cannot continue to be lively without residents. The self-motivation of residents is important for the sustainable development of agricultural villages.
\end{abstract}

KEYWORDS cultural landscape, community, Gassho-style houses, farmland, forest

Received March 26, 2019; accepted May 9, 2019.

\section{Introduction}

\section{The Present and Future Situation of Agricultural Villages in Japan}

In Japan, the population of agricultural villages has been decreasing throughout the 2010s (Statistics Bureau 2012). In 2007, the Ministry of Land, Infrastructure, Transport, and Tourism (hereinafter referred to as 'MILT') stated that there were over 60,000 depopulated hamlets in Japan and that $10 \%$ of them had under 10 households. In addition, there are about 9,000 hamlets having difficulty maintaining their quality of life, and it is expected that 2,643 of them will disappear in the near future (MILT 2007). The number of self-employed farmers has decreased by $60 \%$, from 8,500,000 in 1990 to 3,400,000 in 2015. The land area occupied by commercial farm households has decreased by $30 \%$, from 4,200 hectares in 1990 to 2,900 hectares in 2015 (Statistics Bureau 2018). Agricultural villages in

*This work was supported by JSPS KAKENHI Grant Number JP18K05702.
Japan are declining and disappearing rapidly, and a growing population of aged people has accompanied the collapse of local communities. It is no longer possible to hold community events, such as funerals and traditional festivals, in some villages. Ohno has called these hamlets 'marginal villages' (Ohno 2008, 16).

On the basis of the current situation of agricultural villages, there are three possible ways forward. First, the villagers can keep farming and sustaining their agricultural villages, just as they have in the past. This is the ideal way forward. In the absence of outside intervention, however, most of the 'marginal villages' will be doomed. There are a few examples of agricultural villages that have been revitalised by successful projects. Kamikatsu Machi in Tokushima Prefecture is famous for its 'Tree Leaves Business.' Residents in Kamikatsu Machi founded a company that sells wild leaves from the area's trees to be used as garnishes at top restaurants in Tokyo. Many elderly residents are employed by the company, and some of them 
earn over one million JPY per month (Irodori Cooperative 2019). In another example, an agricultural cooperative in Umaji Mura in Kochi Prefecture began processing $y u z u$ products. Yuzu is a type of orange, and the people of Umaji Mura have traditionally used yuzu in vinegar and spices. In recent years, yuzu has been replaced by ready-made products, and many yuzu trees have been abandoned. Someone working for an agriculture cooperative struggled to develop the market for $y u z u$ products 40 years ago. Today, the market for $y u z u$ products is worth about 30 billion JPY per year (Otoshi 1998). In both villages, there has been a key person with influence. In both cases, they had a good idea and staffed their businesses with local people. The success stories of these villages are famous in Japan, although the population is declining in even these two famous villages. Most agricultural villages do not have such enterprising people. In most villages, the young generation must move to urban areas to look for work, and most farming households have no heir.

The second way forward would be to allow villages to spontaneously become abandoned and disappear. Hayashi wrote that choosing to let them decline is not defeat (Hayashi 2010, 180). The size of the Japanese population had hovered at approximately 30 million until the $20^{\text {th }}$ century. During the $21^{\text {st }}$ century, the population increased fourfold, but it is expected that it will decrease rapidly over the next 100 years (MLIT 2013). In the long term, the population will return to what it was 100 years ago. The decline of the population will improve the degree of selfsufficiency in food production, and it will also decrease damage to the natural environment by humans (Hayashi 2010, 181).

The third way forward would be to conserve agricultural villages as cultural heritage sites, the strategy which is the theme of this paper. Traditional agricultural villages conserved as cultural heritage sites are expected to become tourism resources. Visitors enjoy the traditional landscape, food, and environment in agricultural villages, and the economic effect keeps the villages alive. The Ministry of Agriculture, Forestry, and Fisheries (hereinafter referred to as 'MAFF') indicates 12 diverse functions of agricultural villages. They include not only food production, but also landscape conservation, prevention of natural disasters, dissemination of culture, and so on (MAFF 2015). To put it another way, the current situation of these villages is so critical that the government attaches more importance to their cultural importance than to their potential for food production. In Japan, agricultural villages cannot continue to exist if they rely only on food production, which has historically been their fundamental function. When an agricultural village goes extinct, its tradition and culture die as well. The more villages become extinct, the more traditional culture dies, and it is lost forever. At most, several hundred of the 2,500 disappearing villages will be able to survive as cultural heritage sites. They will be the elite sites chosen to carry out the mission of conserving and passing on the traditions and culture of these areas to the next generation. To safeguard both tangible and intangible cultural traditions, the way that we interpret them must be considered. Agritourism will be an effective way to utilise the capabilities of agricultural villages in the future.

ICOMOS adopted the 'International Cultural Tourism Charter' in 1999. It states that 'Tourism promotion programmes should protect and enhance Natural and Cultural Heritage characteristics.' (ICOMOS, 1999) The economic effect of policies on residents takes top priority in the general context of agritourism. On the other hand, how to interpret historical values and pass them on is the priority of agritourism grounded in the conservation of villages as cultural heritage sites. For example, if a villager wishes to switch from cultivating traditional rice to wheat because it would be more beneficial economically, we should consider the impact on aspects of traditional culture, such as cooperation among the residents, the tools used, and the agricultural techniques used to cultivate different crops. Furthermore, if cultivating new crops results in a major alteration to the landscape and damage the authenticity of the village, switching crops might not be acceptable. The $19^{\text {th }}$ ICOMOS General Assembly adopted the elements 'concerning rural landscapes as heritage' as ICOMOS-IFLA Principles (ICOMOS 2017). It mentioned that 'all rural landscapes have heritage value,' and it stated that it was important to 'prepare effective policies based on informed local and other knowledge of the landscapes' for the protection of rural landscapes.

\section{Authenticity of Agricultural Heritage}

In 1965, ICOMOS adopted the International Charter for the Conservation and Restoration of Monuments and Sites (The Venice Charter) (ICOMOS 1964). The charter said that modifications 'must stop at the point where conjecture begins, and in this case, moreover, any extra work which is indispensable must be distinct from the architectural composition and must bear a contemporary stamp' (Article 9). The Venice Charter aims to preserve archaeological monuments, but some of its provisions are hard to adapt to diverse types of cultural heritage sites; this led to the Nara 
Document on Authenticity in 1994. The document stipulated that 'All judgements about values attributed to cultural properties as well as the credibility of related information sources may differ from culture to culture, and even within the same culture. It is, thus, not possible to base judgements of values and authenticity within fixed criteria. On the contrary, the respect due to all cultures requires that heritage properties must be considered and judged within the cultural contexts to which they belong.' (ICOMOS 1994)

Because people live in agricultural villages, alterations to the landscape and community cannot be avoided. When conserving living heritage sites, we must choose what can be changed and what cannot. The task of showing 'authentic' traditional agricultural villages to visitors presents complicated issues. All matters relating to conservation, from small elements of the landscape to the social system, must be carefully designed to reflect the 'authentic' life of agricultural villages. This paper aims to discuss the design of conservation for agricultural villages through a case study of the historic villages of Shirakawa-go and Gokayama, which are World Heritage Sites.

\section{Conservation of Agricultural Villages as Cultural Heritage Sites: Choosing between Authenticity and Inauthenticity}

How do we conserve agricultural villages where people live? What is the definition of an agricultural village? Is the mere existence of farmland enough to meet the definition? What if the residents do not cultivate farmland and live without revenue from agriculture? Because of questions like these, it can be difficult to define an 'authentic' agricultural village. Agricultural villages can be influenced by the economic and social situation of a country. Hamlets change over time because of changes in the market for agricultural products, land consolidation for mechanisation, and depopulation. The conservation of agricultural villages as cultural heritage sites causes agricultural villages to diverge from their natural state.

When conserving living heritage sites like agricultural villages, the ambiguity surrounding attitudes about authenticity and inauthenticity is a critical issue. The most extreme example would be an amusement park made to look like a farming village. All landscape components, including rice paddies, houses, storehouses, and small rivers, would be newly constructed. Employees would wear traditional farming clothes, and they would pretend to plant rice. Visitors might enjoy cuisine made from the 'harvest'. In this theme park, the experience and landscape of fake agricultural villages would be put on display for mass consumption, and they would be reproduced again and again. John Urry classified tourist sites according to three dichotomies: they may be the object of the romantic or the collective tourist gaze; they may be historical or modern; and they may be presented as authentic or inauthentic. Many well-known difficulties arise from this approach (Urry 2002, 94). He also wrote that 'The gaze is constructed through signs, and tourism involves the collection of signs.' (Urry 2002, 3) He emphasised that 'the heritage history is problematic because of the emphasis upon visualisation. Visitors see an array of artefacts, including buildings (either "real" or "manufactured"), and they then have to imagine the patterns of life that would have emerged around those seen objects' (Urry 2002, 102).

Furthermore, Umberto Eco wrote that 'once the "total fake" is admitted, in order to be enjoyed it must seem totally real' (Eco 1986, 43). Visitors come to agricultural villages to experience an image created by mass/social media. If the satisfaction of visitors is the most important or only purpose, the construction of a new farm village with authentic-looking materials may be rational. This phenomenon can be likened to Disneyland. Eco also wrote that 'Disneyland tells us that technology can give us more reality than nature can' (Eco 1986, 44). The most important thing is not to criticise the concept's resemblance to Disneyland but to understand that conservation of living heritage is a way to retain tangible/ intangible cultural value with a minimum degree of inauthenticity. As a result of conservation efforts, some villages will survive. Their traditional culture will be passed on to the next generation. It is difficult to decide what should be retained to preserve vanishing farm life with as much integrity as possible, and these decisions must be made on-site daily.

On the other hand, the conservation of agricultural villages is beneficial for the residents and local communities, not only for the tourism industry. UNESCO stated that 'The World Heritage Committee specifically encourages the effective and equitable involvement and participation of indigenous peoples and local communities in decision-making, monitoring, and evaluation of World Heritage properties.' (UNESCO 2015) In Japan, residents are concerned with the conservation of their hamlets, whether proactively or passively. It has been said that residents have come to appreciate the values of their home villages through the evaluation process for cultural heritage sites (Working Group for Cultural Landscape 2016, 9). 
Berque, however, gave a critical opinion of such efforts:

Do not confound environment and landscape. Everywhere, a farmer has intimate knowledge of his environment. Thus, if he wants to see it as a landscape, he must learn a special schema for perception, and this schema derives from urban culture.

(For city people) the countryside is nothing but landscape. That is why they are eager to preserve the farmer's house and well pump, which are the signature of rusticity. On the contrary, they disdain spreading the modern urban signature of skylines and advertisements. They are strict guardians of the rural landscape (Berque 1990) (originally in Japanese; translated by the author).

Today, more and more villages have been designated as cultural heritage sites. Some studies suggest that even in areas selected as 'Important Cultural Landscape' national cultural properties, many residents' efforts at conservation do not work effectively. The regional improvement efforts of the next generation are still insufficient (Matsumoto, Akifumi and Masanori 2017).

From the perspective of such discussions about authenticity and the 'urban gaze', we must explore the best ways to conserve these villages, whether city people impose the method of conservation on farmers or the farmers are allowed to decide for themselves. This paper will focus on the concrete elements of a landscape and discuss how to convert agricultural villages into cultural heritage sites.

\section{Conservation Design for Agricultural Villages as Cultural Heritage Sites}

Design is essential for in-situ conservation activities. From tangible elements of landscape to intangible systems, diverse design elements are necessary. The difference between authenticity and inauthenticity is not definitive. A landscape of agricultural villages consists of visible components and a system that must be maintained. Among the many components, this paper will focus on landscape structure, buildings, farmland, and forest, all common components of agricultural villages.

\section{Outline of Shirakawa-go and Gokayama}

Shirakawa Mura is situated in a mountainous region in Gifu prefecture in central Japan. The total land area of Shirakawa Mura is $357 \mathrm{~km}^{2}$. The population comprises about 1,600 people. The forest area covers over $95 \%$ of the region. Ogimachi Village was selected as an 'Important
Preservation District for Groups of Traditional Buildings' in 1976. 'Historic Villages of Shirakawa-go and Gokayama' was inscribed on the World Heritage List in 1995. Three natural hamlets: Ogimachi in Shirakawa Mura, Ainokura, and Suganuma in Nanto city are the World Heritage properties $^{1}$. Shirakawa Mura is an administrative village, and Ogimachi is one of many natural hamlets in it. Shirakawa Mura is a local government, and it designates cultural properties and enacts ordinances. The local government organises committees for conservation of cultural properties and gives administrative guidance on what constitutes development beyond an acceptable level.

Natural hamlets like Ogimachi Village are traditional entities from the Edo period. Today, the residents of Ogimachi Village work together at festivals, funerals, and regular cleanings of common spaces. Suganuma and Ainokura Villages belong to Nanto city. Each natural hamlet used to have a small local government. In 2004, they were annexed by Nanto city. This paper mainly discusses a case study of Ogimachi Village because it is good example of conservation of an agricultural village as a cultural heritage site.

\section{Elements of the Landscape}

The elements of the agricultural landscape are farmland, forests, buildings, roads, trees, and canals. In Ogimachi, Ainokura, and Suganuma Villages, sericulture continued until the early $20^{\text {th }}$ century. Gassho-style houses are the most important architectural element in these areas. These houses have a unique style that cannot be found in any other region in Japan (Figure 1).

Forest, farmland, and Gassho-style houses used to have a strong relationship with each other. This paper focuses on landscape structures first, then discusses Gassho-style houses, forests, and farmland. These three elements are integral to the village landscape. Gassho-style houses and forests are used as case studies for Ogimachi Village, and farmland is used as a case study for Ainokura Village.

\section{Landscape Structure}

Traditional hamlets have been tailored to their natural and social environments. There are rational reasons for the arrangement of buildings, direction of doors, and development of roads and canals. The rooflines of the Gassho-style houses in Ogimachi Village are lined up parallel to the Sho River. One of the reasons for their alignment is to facilitate the drainage of melting snow on both sides of the roofs in the winter and to keep the inside of the Gassho well-ventilated for sericulture. The guidelines 


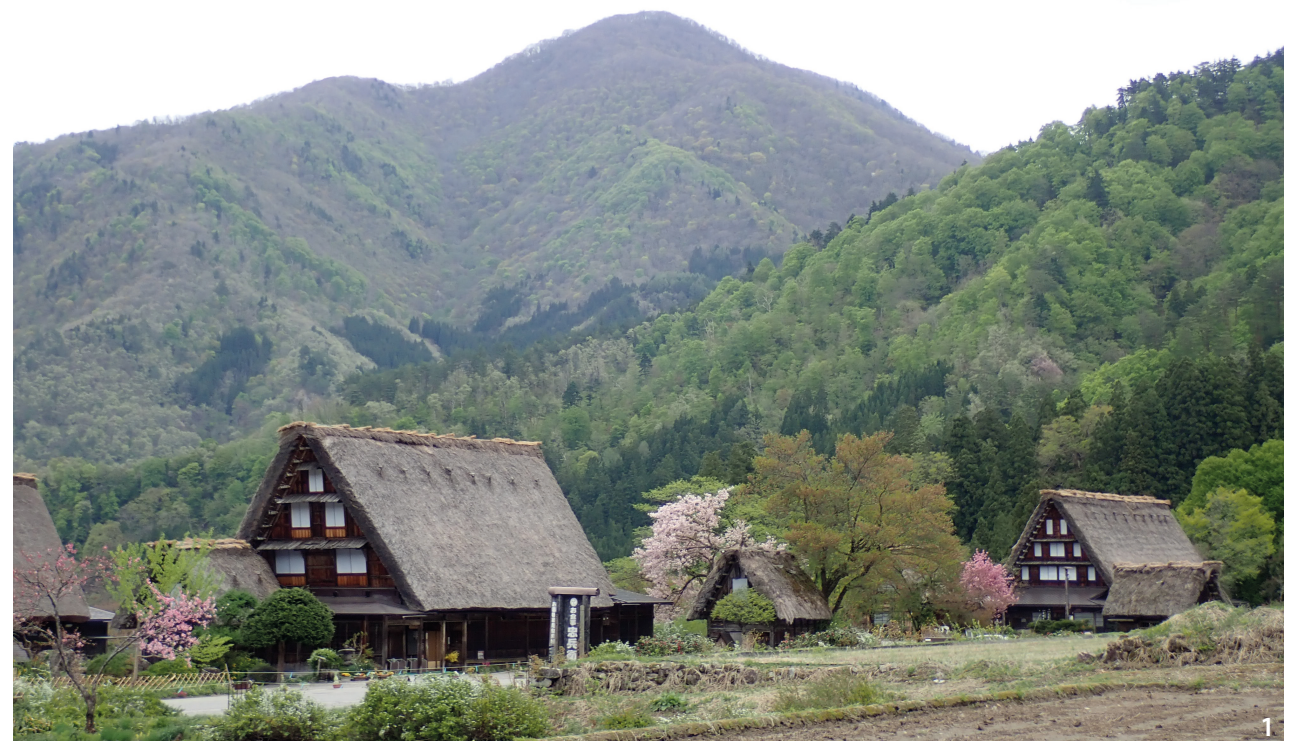

Figure 1 Gassho-style houses in Shirakawa mura Ogimachi village (Source: the author). for landscape preservation in Shirakawa Mura specify that 'The rooflines of houses shall be arranged in a north-south manner that is parallel with the ex-national and national roads, the mountain, and the river.'

There was previously a Gassho-style house that did not meet this requirement. In 1971, before the village's selection as a cultural property in 1976, the building was relocated from another village to Ogimachi Village for the purpose of opening a souvenir shop. Because of the limitations and shape of the land, the building was placed at a $90^{\circ}$ angle to the other buildings. Accordingly, snow remained only on the north side of the roof, which wore out much faster than the south side of the roof. In 2010, the owner decided to restore the house. Before relocation, the house originally stood at a north-south orientation and was $3.3 \mathrm{~m}$ too long in the ridge direction in another village named Kazura. On the basis of this scientific premise, the house was rotated $90^{\circ}$ to stand parallel with the other buildings and the missing $3.3 \mathrm{~m}$ part was added. The wood of the added part was left unpainted, and thus visitors could identify that the added part was not original. The large Gassho-style house was tailored to the village's landscape structure and the landscape of the whole village improved (Figures 2, Figure 3). After restoration, residents closed the souvenir shop and opened a small private museum.

The scientific premise adopted in the restoration of this building is tricky from the perspective of authenticity. It is unclear whether the setting of a different hamlet was enough to prove its authenticity. According to an architect in charge of Shirakawa Mura, he needed an objective evidence to prevent other residents from applying to make major alterations to traditional buildings without any evidence. It comes down to whether the evidence was enough to prove authenticity.

\section{Buildings}

In Japan, most of the agricultural villages were formed spontaneously, except for those that had to be fully rebuilt because of dam construction or large natural disasters. Houses have been built continuously over time according to degradation of existing buildings and generational changes. 'Important Preservation Districts for Groups of Traditional Buildings' is a category of Japanese cultural property. Buildings with historic value are designated as being a part of such districts. Accordingly, this system divides all houses into two types: historic and non-historic buildings. Historic buildings should maintain their original façades, but changes are allowed inside houses. Important cultural properties, which are usually unique buildings, must not be modified on the inside without permission from the commissioner for cultural affairs. This is the big difference between important cultural properties and designated historic buildings in Important Preservation Districts for Groups of Traditional Buildings. Residents and owners of historic houses can change room layouts in accordance with modern innovations and household needs. The government subsidises the repair of the façades of the houses. Buildings other than historic houses are bound by regulations concerning repairs and new construction. 

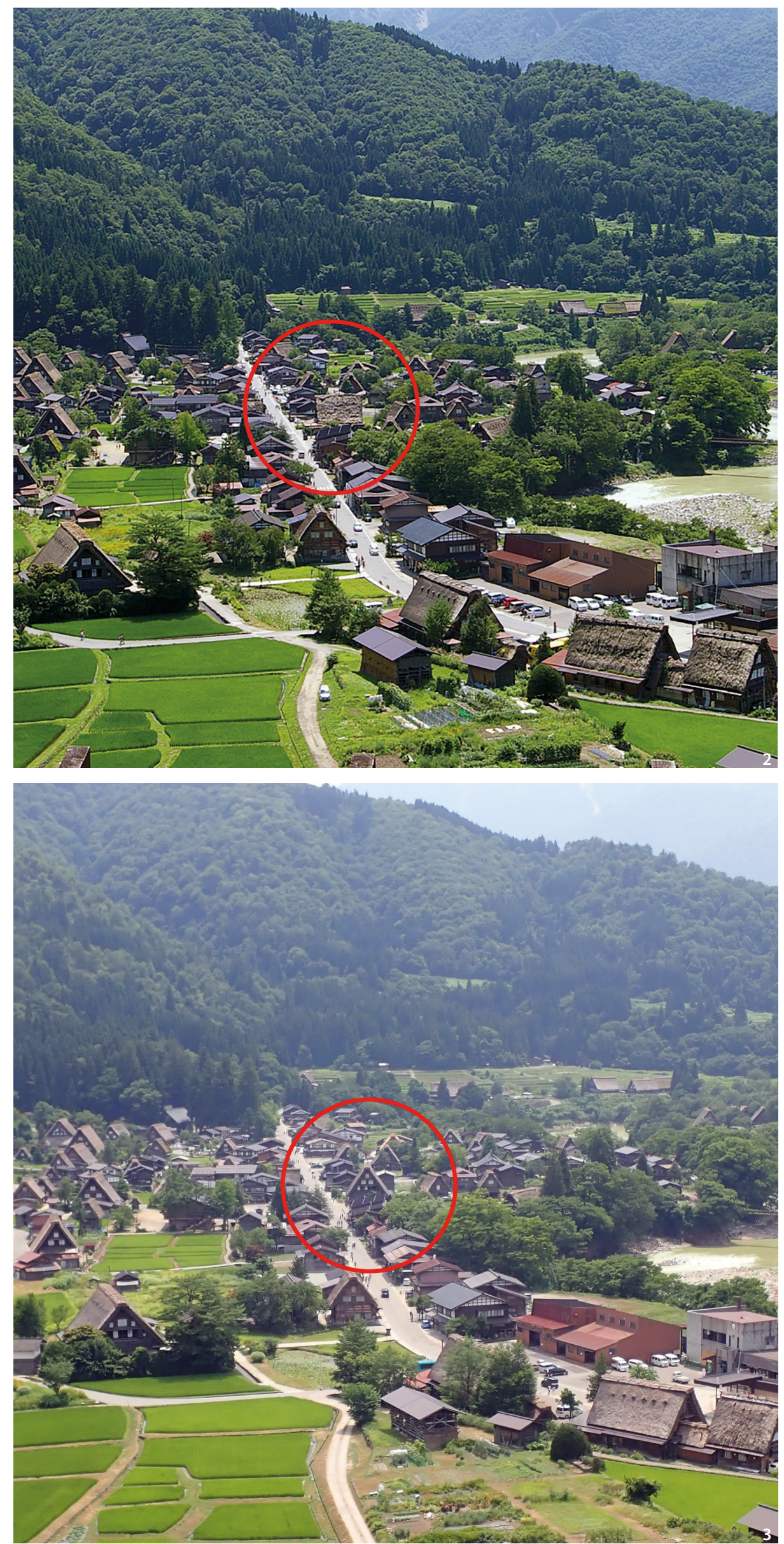

Figure 2 Gassho-style house in 2009: Before restoration (Source: the author).

Figure 3 Gassho-style house in 2018:

After restoration (Source: the author). 
The most important elements of Ogimachi Village are Gassho-style houses. These houses have a distinctive structure that has never been seen in any other region of Japan. Most Gassho-style houses were built between the early $19^{\text {th }}$ century and the early $20^{\text {th }}$ century. One of the biggest Gassho-style houses is $11 \mathrm{~m}$ high. The insides of the roofs of Gassho-style structures were first used for sericulture (ACA 1996, 66).

The preservation plans of Ogimachi Village were revised in 1994 with its inclusion on the World Heritage List. New preservation rules note that 'Construction of imitation Gassho-style houses, except for reconstruction based on scientific grounds, is prohibited.' (Shirakawa Mura 1994) This article was derived from the Venice Charter by ICOMOS. To differentiate Gassho-style houses from non-historic buildings, the construction of new Gassho-style houses is prohibited.

Residents and owners of Gassho-style houses can change the inside of such buildings provided that the changes do not impact the façade of a building. Furthermore, they may expand Gassho-style houses by less than half the size of the original structure or under $100 \mathrm{~m}^{2}$. The height of the lower part of the building (which is an addition to the main structure) must be within $4.2 \mathrm{~m}$ (Shirakawa Mura 1999). Because of this regulation, many Gassho-style houses have façades like the one in Figure 4. Some of the buildings have been extended in two directions, and they have become very different from the original Gassho-style house (Figure 5). As of 2019, there were 59 Gassho-style houses designated as traditional buildings at World Heritage Sites: 20 provided lodging, 10 were restaurants, night were private museums, five were souvenir shops, and 15 were dwellings or vacant houses ${ }^{2}$. Three quarters of the Gassho-style houses were used for tourism-related purposes. The owners opened the main rooms to tourists, and the extensions were used as dwelling areas, washrooms, and restrooms.

Non-historic buildings are bound by regulations as well. Residents are prohibited from constructing new buildings on farmland, but they can rebuild a house on the same premises. Design details, such as the fixtures of doors and windows, building materials, and paint colors, as well as permitted types of snow-removal devices, are strictly specified (Figure 6). New buildings constructed according to the regulations are called 'mountain cabins' because of their appearance. They all have the same appearance and lack of individuality, so they are obscured by the village landscape.

In Shirakawa Mura, there are Gassho-style houses and other types of buildings. The regulations for both types of buildings work well. Because of the popularity of the tourist industry, most Gassho-style houses have been altered to accommodate changes in their usage. There are unique regulations to prevent the construction of inauthentic Gassho-style houses, but the question of how to determine the authenticity of Gassho-style houses is open to interpretation.

\section{Farmland}

Farmland is one of the most distinctive elements of agricultural villages. Villages without farmland are not agricultural villages. Despite this fact, the conservation activities of agricultural villages tend to be focused on buildings rather than farmland. In Japan, changes to the use of farmland are restricted by several laws ${ }^{3}$. In fact, deserted cultivated land is increasing yearly. In modern times, much of Japan's farmland has become consolidated. In order to cultivate farmland with machines, small rice paddies were consolidated into large ones. The shape of the land changed from a natural curve to a straight line. This farmland consolidation occurred all over Japan, and small, wet paddies unsuitable for mechanisation have been left behind for small farmers as a result. The remaining farmland is hard to cultivate, especially for elderly people, and the paddies are slowly being abandoned.

Ainokura Village is located in Nanto city and is a World Heritage Site like Ogimachi Village in Shirakawa Mura. There are 18 households, and 54 people live in the village (Nanto city 2017). In Ainokura Village, people used to cultivate mulberry trees for silkworms in addition to a few vegetables for subsistence. Silkworms for sericulture eat enormous amounts of mulberry tree leaves. At one time, there was strong relationship between Gassho-style houses and farmland. With the decline of the silk industry, mulberry fields were discarded. In the 1940s, canals were constructed from distant rivers to Ainokura Village, and hence residents converted their farmland from mulberry fields to rice paddies (Nano City 2012, 48). At the time, villagers eager to eat white rice harvested it from their own paddies. Soon after the canal construction, the Japanese government decided to cut rice production because of the oversupply. At the same time, depopulation and aging were becoming issues in Ainokura Village. There were four hectares of farmland in Ainokura Village, and half of them had been abandoned. Thus, the relationship between houses and farmland was lost along with the transition from mulberry to rice and abandoned fields.

In Ainokura Village, preservation regulations were adopted in 1996. It was noted that the shape of the 

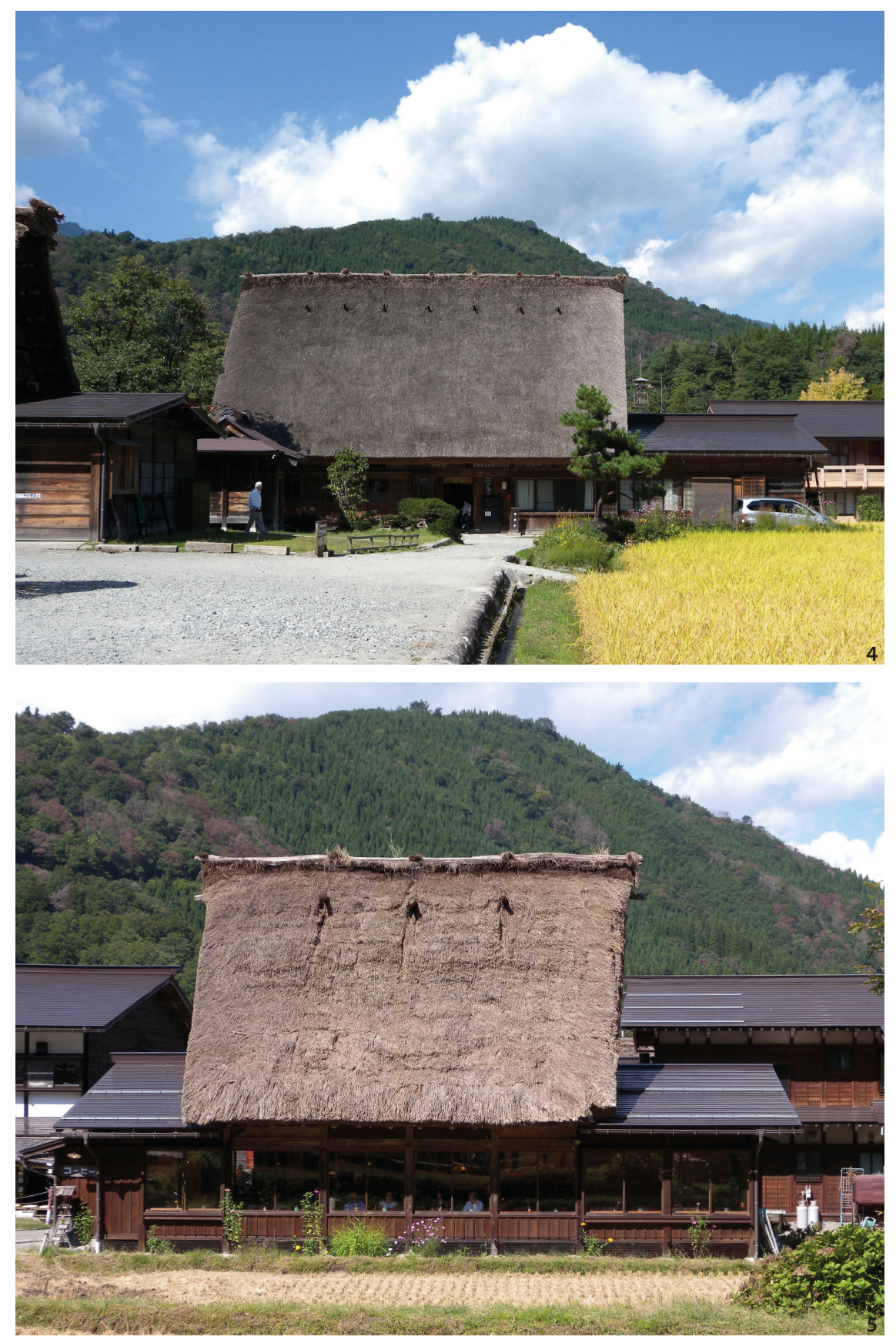

Figure 4 Gassho-style house with extension (Source: the author).

Figure 5 Gassho-style house with extension on both sides (Source: the author).

farmland should be kept unchanged; modernisation to increase productivity and convenience may be taken into account only without damage to the landscape' (Taira Mura Board of Education 1996, 18). Nanto City developed a Conservation Master Plan for Gokayama (Nanto city 2012). It focused on the fact that aging and depopulation had caused farmland to become abandoned. In response to this agenda, the government decided on some guidelines for farmland. They stipulated that the shape of farmland and its boundaries must remain unchanged and that minimum maintenance, such as mowing abandoned farmland, was required. The guidelines were vague, and not much had changed from before, but it was the minimum amount of regulation considered acceptable in today's social environment.

Since 2005, there has been a drive to revitalise farmland. The Gokayama agricultural cooperative operates a project called 'Farming day for everybody in Gokayama'. The program allows urban participants to become temporary owners of rice paddies. Participants pay 20,000 JPY, plant rice in May, and harvest it in September (Figure 7). They receive $30 \mathrm{~kg}$ of rice along with special local foods ${ }^{4}$. Members of the agricultural cooperative teach participants how to cut and tie rice straw. These 
III. Rules for improving buildings other than traditional buildings.

1. Buildings other than traditional buildings are not designated as traditional buildings

2. Design and materials for façade

Painting the wooden portion of the façade

For new construction, natural or faded colours shall be used to create an antique look. For additions and reconstruction, faded colours shall be used.

Basically, the roof style shall be kiritsuma (gable roof) for at least twothirds of the whole roof. The material of the roof shall be either metal boards (Kawara-bo style, flat roofing, or Yoko-buki style) or Japanese roof tiles that are dark brown or black. The roof ridgelines of houses shall be arranged in a north-south manner that is parallel with the exnational and national roads, the mountain, and the river.
Facility

The design of any snow-removal devices shall be in harmony with the surroundings and approved by the Association for the Protection of the Natural Environment of Shirakawa-go Ogimachivillage (hereafter, collectively called "the Association").

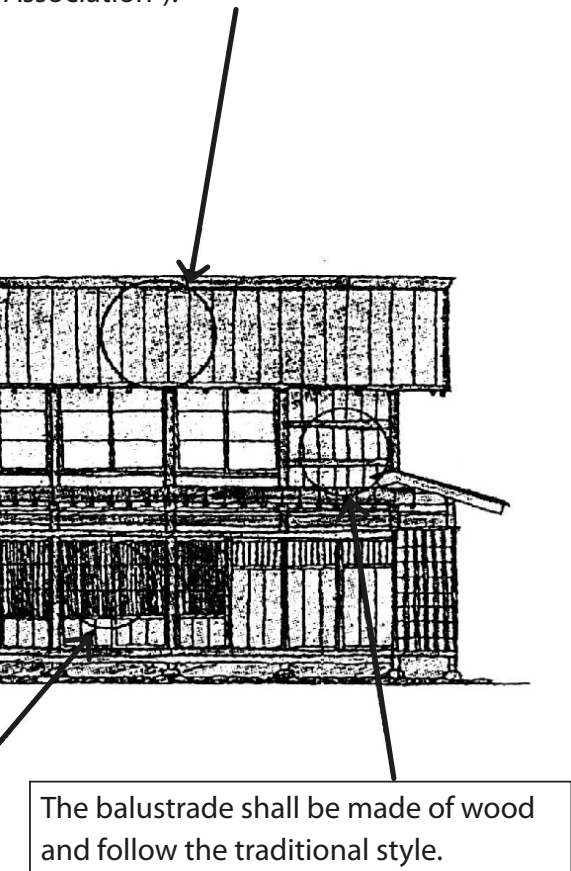

Colours shall be natural or antique.

ixtures are to be traditional style (please cite 2-1.) The colour shall be natural or antique. If aluminium sashes are used, they shall be coloured bronze.

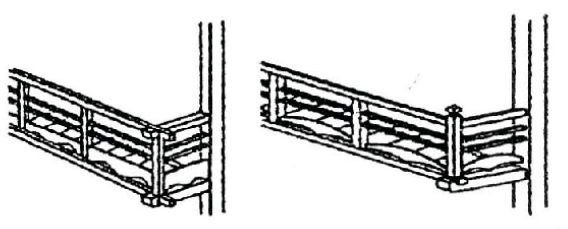

The wall shall follow the traditional style. The traditional style is nuki-arawasi with yoko- or tate-itabari (horizontal- or vertical-boarded), tateitabari (vertical-boarded), sitami-itabari and plastered wall, etc. Mortar walls and metal boards can only be used with permission from the Association.

The colour of materials is natural or antique. Plastered walls shall be white or the colour of dirt. For metal boards and others, the colours must be approved by the Association.

Figure 6 Preservation Rules for the Shirakawa-Mura Ogimachi Preservation District for Groups of Traditional Buildings (Source: Shirakawa mura 1999). 


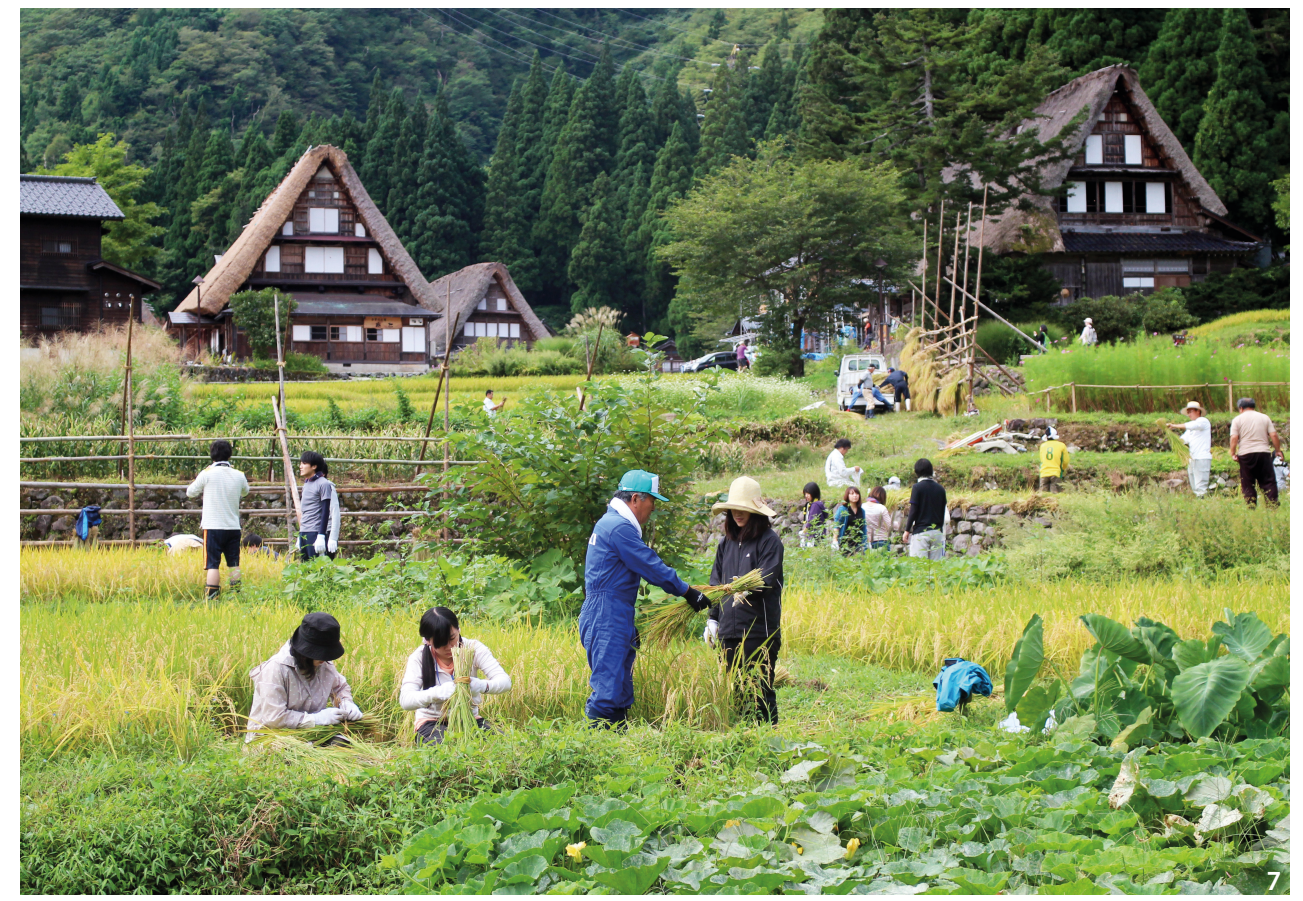

Figure 7 Harvest event in Ainokura village (Source: the author). agricultural experiences satisfy the needs of participants. However, there are some problems with this project. It is operated with subsidies from the government, and it does not generate a profit. The Gokayama agricultural cooperative rents residents' farmland for the project, but there are few opportunities for participants to meet the residents of Ainokura Village.

There has been research on tourists' perceptions of farmland in Ainokura Village (Haruna and Kuroda 2010). Based on a questionnaire, it can be observed that tourists prefer rice fields to vegetable and mulberry fields. More than $90 \%$ of tourists believed that the farmland in the area should be maintained because it is located at a World Heritage Site. Regarding the question of how to conserve the farmland, $60 \%$ of respondents believed that the government should be responsible for the conservation of farmland. Others believed that agritourism, subsidies for residents, donations, and volunteer efforts could be implemented to conserve farmland, but these accounted for no more than $30 \%$ of respondents' answers. Visitors think farmland must be conserved, but they do not show much ownership of it.

As Berque noted, for many tourists, the farmland of Ainokura Village is nothing but a 'landscape'. Replanting mulberry fields is the ideal means of demonstrating the value of Gassho-style houses. In Shirakawa Mura and Gokayama area, sericulture stopped in 1970s. Replanting mulberry trees has no meaning without revitalising the sericulture industry, however. To reconstruct an authentic landscape, encouraging residents to engage in sericulture and plant mulberry fields may be the ideal strategy, but it would be impossible under the present circumstances. The landscape of Gassho-style houses and rice paddies is beautiful year-round. Tourists enjoy the landscape and eat the rice at the restaurants and inns. The relationship between buildings and farmland has changed so that the tourism business, not agriculture, is the main source of income.

\section{Forest}

The forest is intertwined with life in agricultural villages. Forests used to supply many vital resources: wood for the construction of buildings, wood for fires, grass for compost, nuts, wild mushrooms, and animals that could be hunted for meat. The forest near a hamlet was maintained as grassland or open deciduous forest, and people looked to it for many daily necessities. In Japan, this kind of forest is called a satoyama. 'The satoyama landscape is characterised by a mosaic of diverse land uses, and it includes woodlands, grasslands, rice paddies, farmland, irrigation ponds and canals, and human settlements, all of which have been maintained in an integrated manner.' (IPSI 2019, Ishizawa 2018) A satoyama integrates the character of the natural environment into the landscape.

The materials of an old farmhouse show the composition of the satoyama landscape at the time of its construction (Oku and Murakami 2011). The intimate relationship between nature and farm houses is common in East Asian countries. The chona-bari beams of Gassho-style 

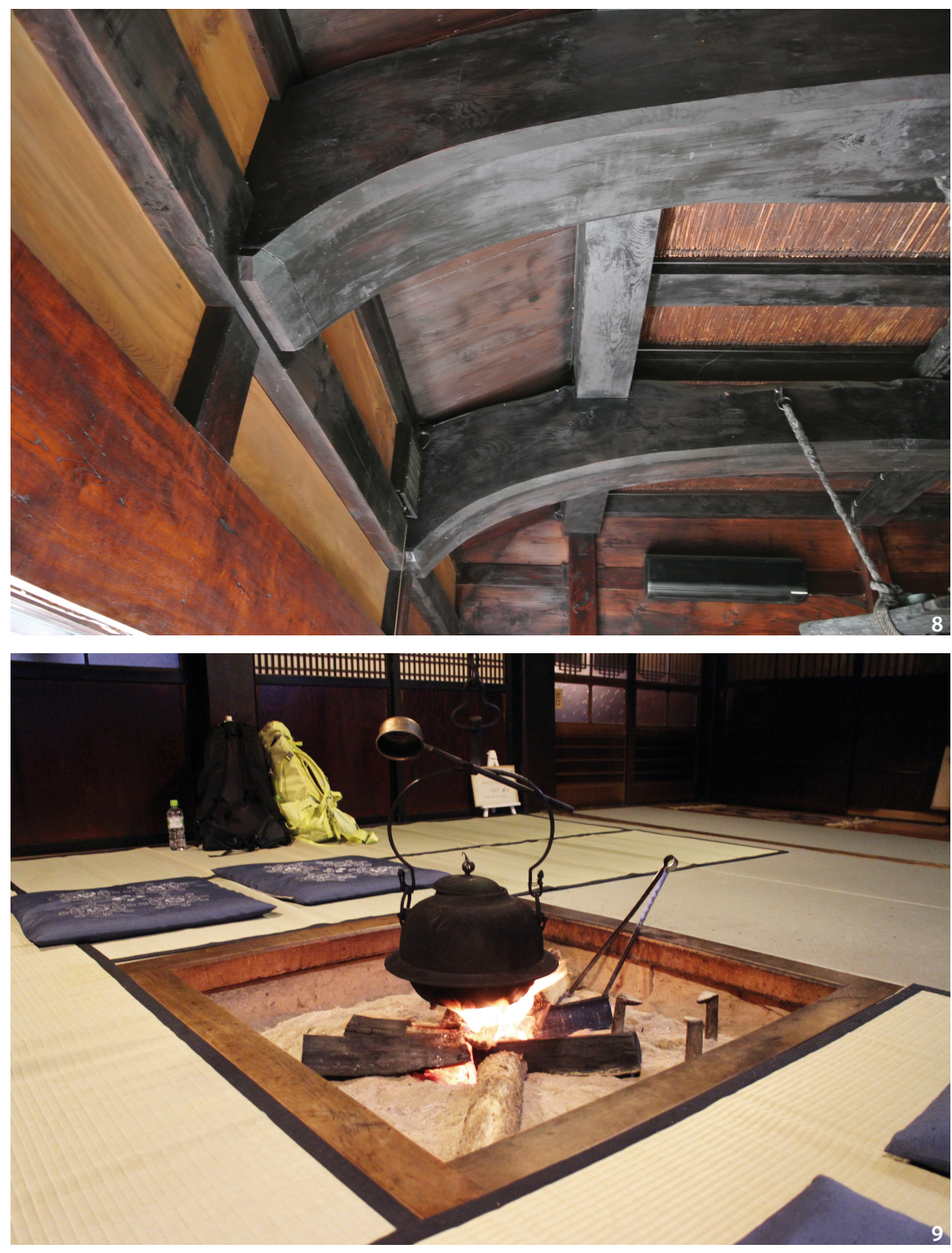

Figure 8 Chona-bari beam of a Gasshostyle house: Snow-bent woods enhance the structure (Source: the author).

Figure 9 Irori: Fireplace in a Gassho-style house (Source: the author).

houses come from trees that grow on steep mountain slopes where the tree trunks are naturally forced into a curved shape by snow (Figure 8 ). With this curved shape, the beam has increased strength, serving as a natural arch. Fuel is also derived from natural products. There are fireplaces called 'irori' in Gassho-style houses, and firewood is used as fuel (Figure 9). Irori are necessary not only for cooking but also for heating silkworms. The smoke of burning firewood is effective in preventing the degradation of a roof. Today, there are a few private inns that use firewood for tourists, but in many Gassho-style houses, the fuel source has changed from firewood to charcoal, gas, and petroleum. This change has also shortened rethatching intervals.

In Ogimachi Village, not only the farmland but also the forest has changed dramatically since the $19^{\text {th }}$ century
(Kuroda 2002). Until the $19^{\text {th }}$ century, there were fields for crops in the forest. Because Ogimachi Village is surrounded by steep mountains, there is little flat land suitable for cultivation. Fields for crops continued to exist until 60 years ago, but most of these fields have now disappeared. Figure 10 is a map of forest use in 1843. The areas occupied by grasslands, Kaya fields, and planted trees are also indicated on the map. At that time, the government began to regulate the usage of mountain areas, and diverse vegetation formed a mosaic-like landscape. As in other parts of East Asia, slash and burn agriculture was practiced in Ogimachi Village. First, farmers planted soybeans or buckwheat, following which they planted vegetables (Shirakawa Mura 1998).

The Kaya used to construct the roofs of Gassho-style houses is grown in the mountains. Each household used 

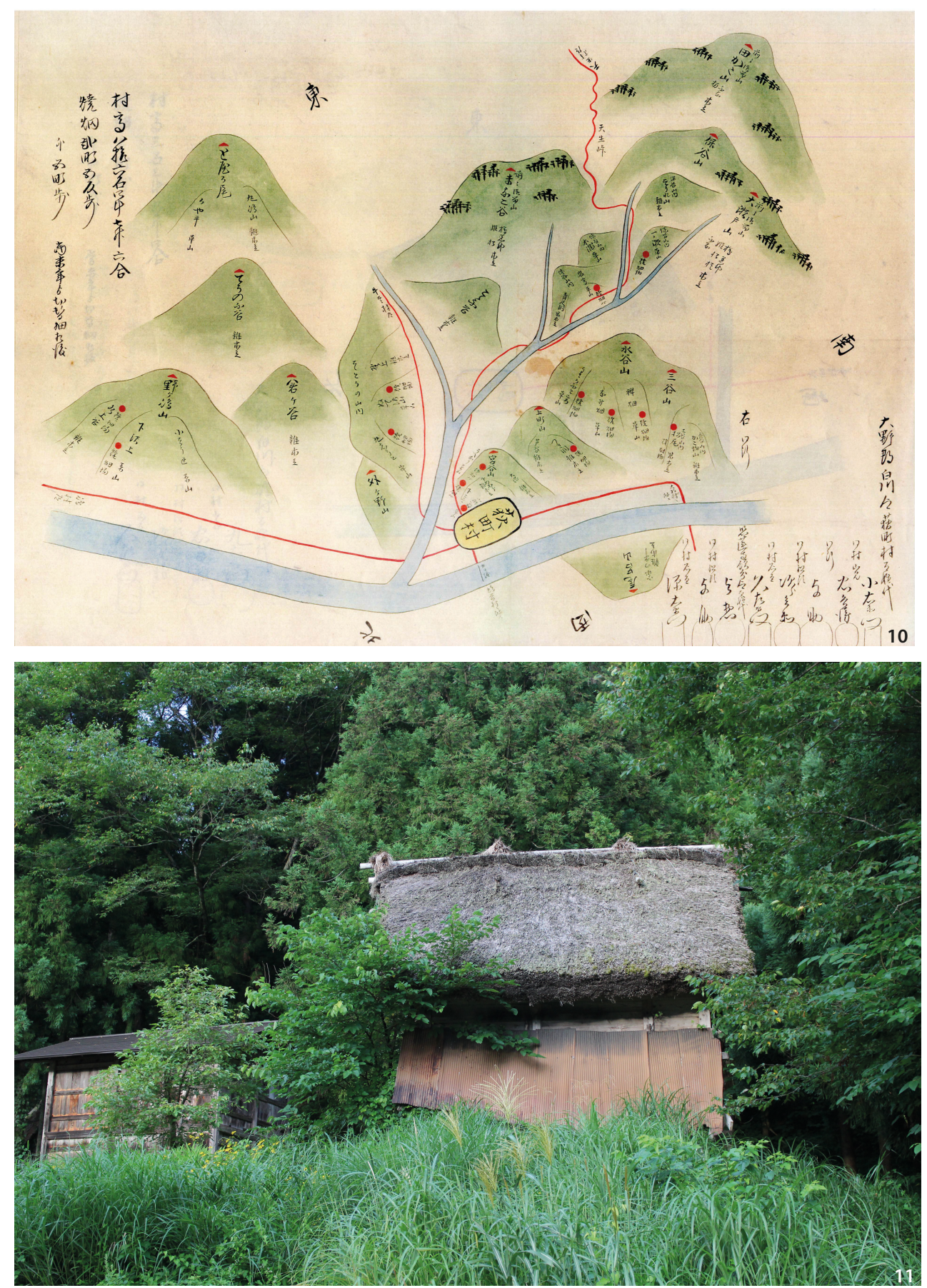

Figure 10 Tenpo Yama Ezu: Map of forest use in 1983 (Source: Shirakawa mura archives).

Figure 11 Gassho-style store house damaged by artificial forest (Source: the author)

to have its own Kaya field. There are two types of Kaya. A traditional species called 'Kariyasu' is thin and small, and a common species called 'Susuki' is thicker. The inside of Kariyasu is hollow, but the inside of Susuki is not. Thus, traditional Kariyasu drains water much better than common Susuki. People used to use traditional Kariyasu. Because Kariyasu grows only in high-altitude mountain areas and needs more maintenance than Susuki, many roofs are now made from Susuki instead of with traditional Kariyasu. Today, some of the Kaya is purchased from outside of Ogimachi Village.
In Japan, the national government has encouraged the cultivation of Sugi (Cryptomeria japonica) in anticipation of future demand for timber. The import of wood from other countries, which is much cheaper than domestic wood, has become common, and the forest industry has declined rapidly. Sugi forests have been left unmaintained. To make the situation worse, pollen from derelict Sugi forests causes allergies. In Shirakawa Mura, these government policies have influenced the village landscape. Abandoned slash-and-burn fields and Kaya fields have been converted to new Sugi forests. Today, 


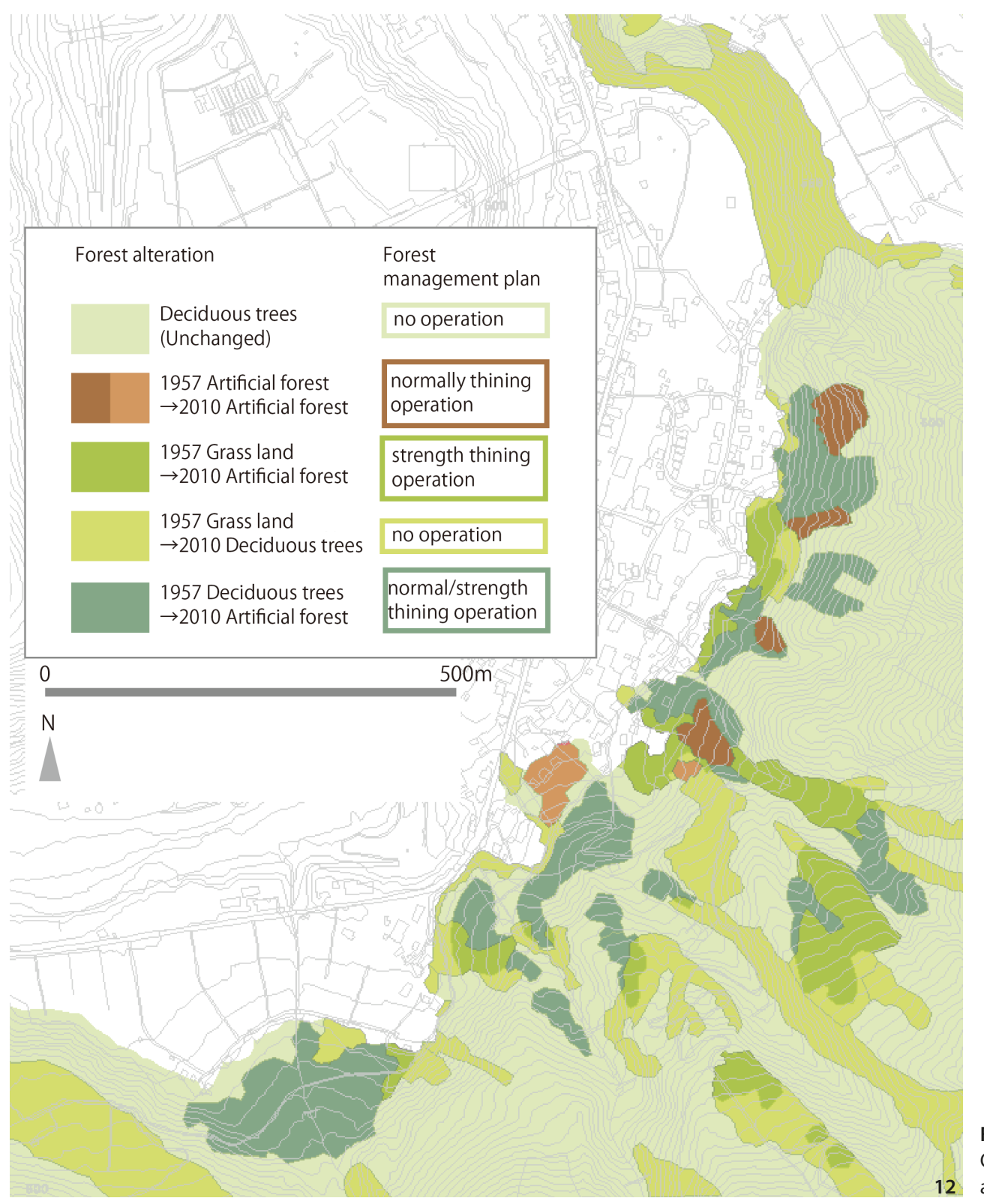

Figure 12 Transition of forest in Ogimachi Village (Source: the author).

Sugi trees are left untended, and they grow large. Brush and leaves from the trees cause damage to the roofs of Gassho-style houses (Figure 11). The forest is dark, even during the day, and it is treacherous. To devise a plan for forest management in the marginal areas of World Heritage Sites, local government asked the author to analyse changes in forest vegetation. Figure 12 shows changes in vegetation between 1957 and 2010. The marginal forest areas surrounding villages have changed drastically. Most grasslands, and some of the deciduous trees, have been converted to artificial forests. Severing the link between villagers and the forest is a large factor in these changes. To maintain the landscape of this World Heritage Site, the local government plans to maintain the forest area adjacent to the village.

\section{Design of Management Structure}

\section{Process of Permission}

There must be regulations outlining which types of alterations are allowed in the conservation of a living village. In Japan, detailed guidelines controlling elements such as the color and height of buildings are determined by conservation plans or local ordinances. Preservation ordinances and plans must be enforced in all Important Preservation Districts for Groups of Traditional Buildings, including Ogimachi Village.

In Ogimachi Village, if a resident wants to make changes to a building or land surface, he or she must apply for permission. Figure 13 shows the process of asking for permission to make alterations. The construction plans 


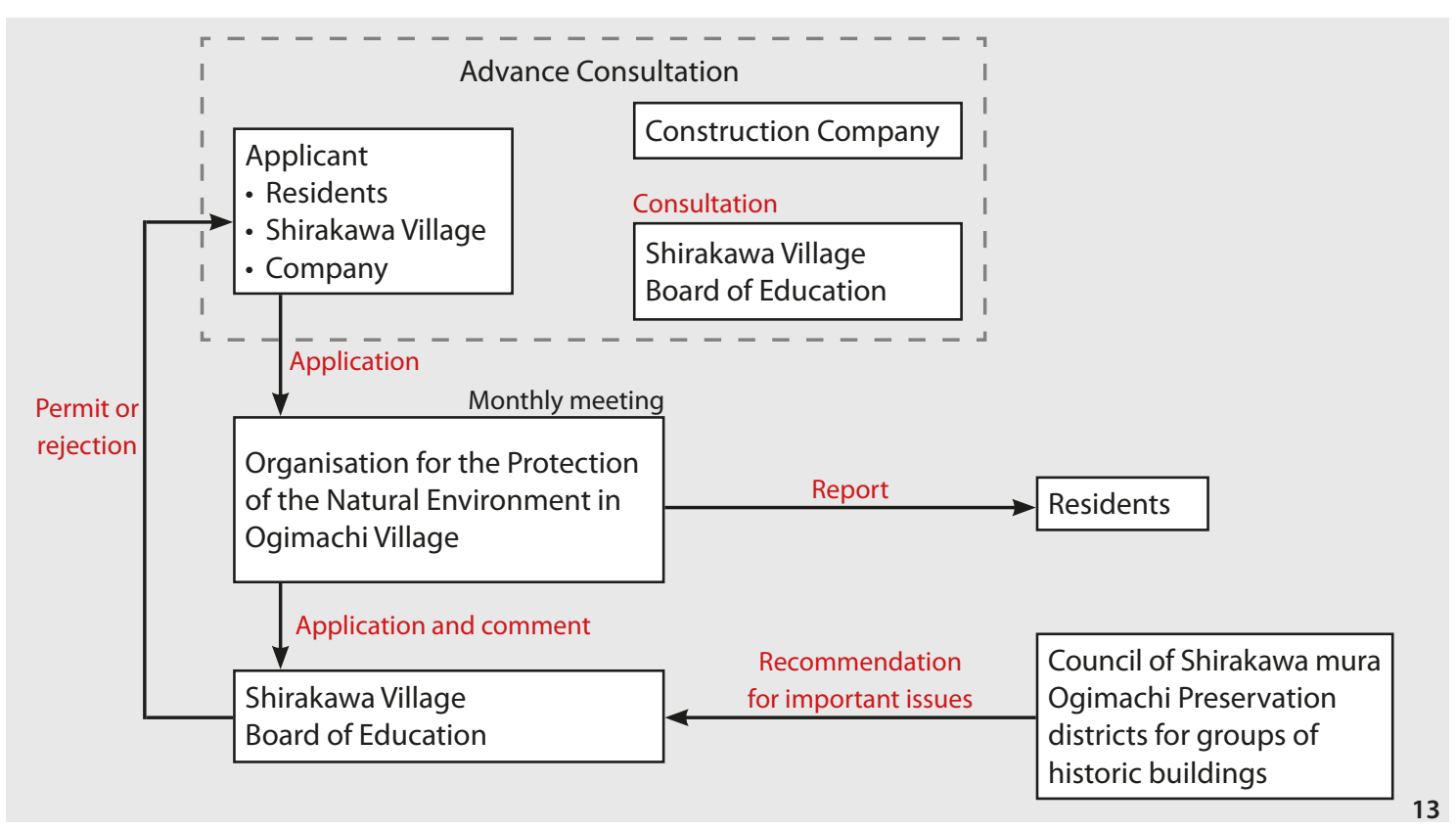

Figure 13 Permission process in Ogimachi village (Source: the author).

of all buildings, whether or not they are designated as historic buildings, must receive approval from the local government. First, the applicant must consult an architect from the Shirakawa Mura Board of Education ${ }^{5}$ and a construction company about the changes. He or she must then apply to make changes to the building or land. The residents' organisation reviews the application and decides whether to grant permission or advise the applicant to modify the application. The council of the Shirakawa Mura Ogimachi Preservation District for Groups of Historic Buildings discusses issues such as public buildings and large scale construction, and it makes recommendations to the Board of Education. This process seems complicated because both the residents' organisation and the Shirakawa Mura Board of Education play an important role. In this process, there are only a few specialists on the council who are not residents of Shirakawa Mura. Almost all stakeholders live in Shirakawa Mura. Because Shirakawa Mura is a small village with only 1,600 residents, people know each other's family circumstances. This close relationship makes the process flexible.

\section{Residents' Organisations}

As mentioned above, the Organisation for the Protection of the Natural Environment in Ogimachi Village has been effective in implementing regulation processes. In Ogimachi Village, the residents began to undertake conservation activities as early as the 1970s. It was difficult for residents to understand the idea of preserving the old houses they were living in at the time, but the younger generations assembled people, again and again, until everyone was convinced and agreed to participate. The organisation was formed in 1974. They established a charter with the consent of all residents, and they promised to protect the Gassho-style houses and the natural environment themselves. According to one of the first members of the organisation, 'At first, we did not mean to preserve our cultural heritage but to speculate on how we could survive in this isolated mountain village in the future.' (OPNEOV 2011, 42)

Delegates from various districts, tourist associations, and women's societies make up the organisation's membership. All members live in Ogimachi Village. This is the reason that the organisation has been effective in conserving the village for over four decades. Since ancient times, the sense of community of traditional agricultural villages has been passed down to younger generations. In Ogimachi Village, the membership of the community has largely remained the same over the years. If outsiders performed a key administrative role in the conservation process, it would not be successful. These days, the young generation tends to think of the close relationships between residents in their local communities as bothersome, and they leave their villages. Recently, however, there has been a new trend in Japanese agricultural villages. Odagiri noted that the number of young people moving from urban areas to agricultural villages has increased over the past ten years. They think that the atmosphere of villages 


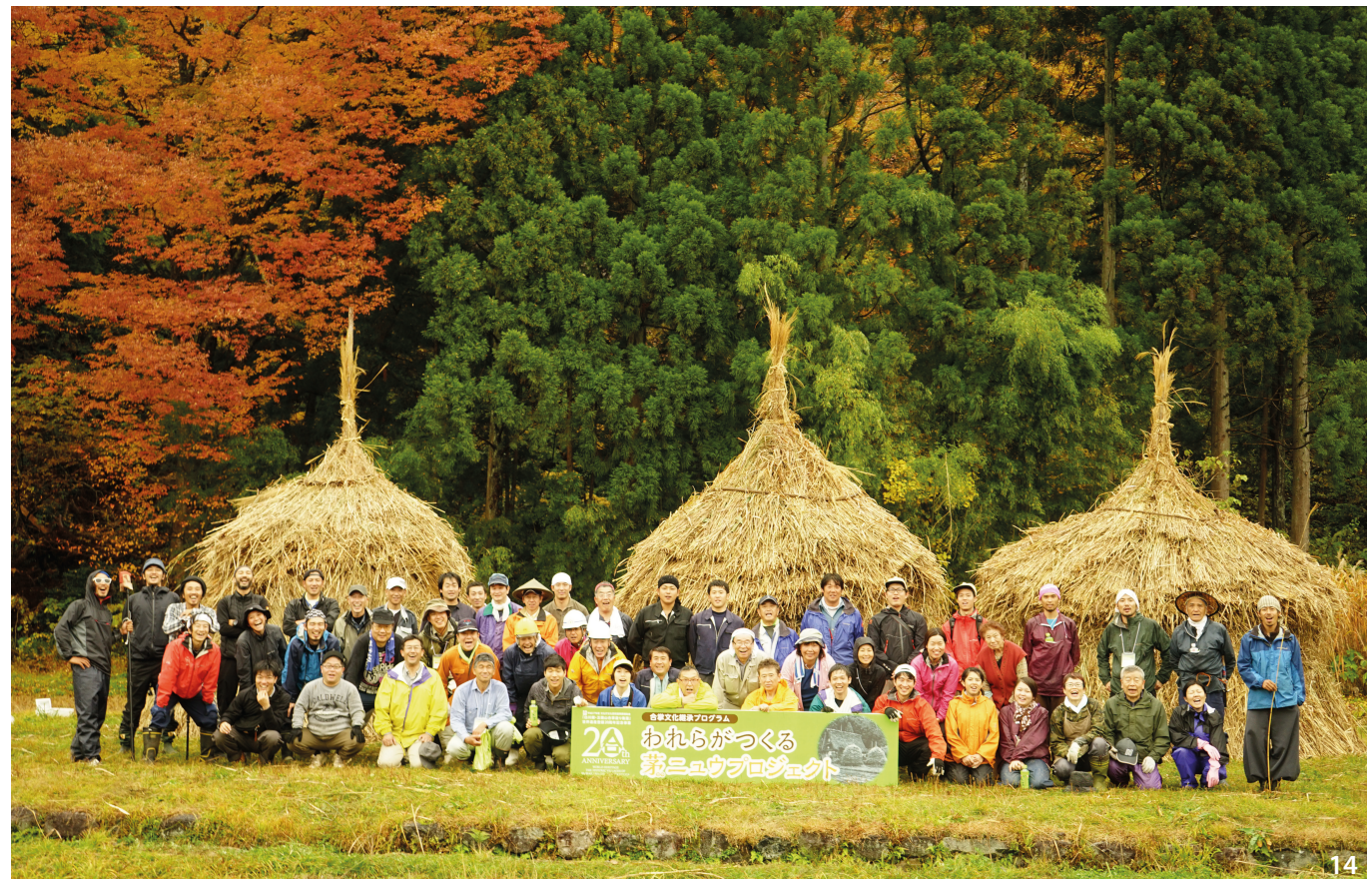

Figure 14 Resurgence of "Nyu," the traditional means of storing Kaya (Source: Shirakawa mura archives). is much warmer and friendlier than that of the city. Elderly people in agricultural villages have a lot of traditional knowledge, and young people respect them. For them, traditional culture is stylish and exciting (Odagiri 2017, 176). In Ogimachi Village, many members of the young generation have returned and started working in the tourism industry. Their experience of city life has taught them to appreciate their home villages. They have integrated themselves into the traditional culture and the community, and the villagers have been inspired by the newcomers. Thus, the community is slowly becoming revitalised.

\section{Conclusion}

The crucial elements of Japanese agricultural villages are Gassho-style houses, and each element of their construction has a relationship to daily activities such as agriculture and sericulture. The previous relationships between each element were organic and covered a wide area, from the settlement to the forest. Today, people's relationship with nature has become tenuous, and activity in the forest areas has declined. To pass on the traditions and culture of these villages to next generation, creating new links between each element is necessary.

Berque noted that villagers learn special schema for landscape perception derived from urban culture, and city people want to preserve the signature of rusticity. In Shirakawa Mura, residents have already honed their sense of landscape perception over several decades, and they have been trying to find the best way forward, even if it involves outsiders. As one of the $20^{\text {th }}$ anniversary of the World Heritage inscription events, the young generation tried to revive 'Nyu', a traditional means of storing Kaya. Elderly people taught them how to make $\mathrm{Nyu}$, and residents from both inside and outside Ogimachi Village participated (Figure 14). This is a good example of the revitalisation of village culture and of creating a new link between the past and the present.

An agricultural village cannot continue to be lively without residents. Even if a beautifully designed farm village where no one cultivated fields or lived their lives was constructed, it would not be an agricultural village. Many agricultural villages in Japan will disappear spontaneously. Only some of them will be selected for conservation as cultural heritage sites. They will become treasured examples of traditional agricultural villages. The self-motivation of residents is an integral part of sustainable development for agricultural villages. The preservation of heritage should not be forced on villages by the government or outside forces against the residents' will.

\section{Notes}

1. Shirakawa Mura is an administrative village, and Ogimachi Village is a natural hamlet. Ainokura Village and Suganuma Village are also natural hamlets.

2. Numbers are based on research by the author of this paper.

3. Act on Establishment of Agricultural Promotion Regions and Cropland Act. 
4. The author has participated in the project since 2007. University students also experience learning through harvesting rice.

5. Board of Education is responsible for conservation of cultural properties in many local municipalities of Japan.

\section{References}

ACA (Agency for Cultural Affairs, Government of Japan). 1994. "The Historic Villages of Shirakawa-Go and Gokayama, Traditional Houses in the Gassho Style.” Accessed 20 June 2019. http://bunka.nii.ac.jp/suisensyo/ shirakawago/start.html

Berque, Augustin. 1990. Nihon no Fuukei Seiou no keikan: Sosite zoukei no jidai [Japanese Fuukei and Western Landscape: For Creation of Landscape]. Tokyo: Kodansha.

Eco, Umberto. 1986. Travels in Hyperreality (Harvest Book). Boston: Houghton Mifflin Harcourt.

Haruna, Mirei, and Kuroda Nobu. 2010. "A Study on the Farmland Conservation in Gokayama Ainokura Village." Landscape Research Japan 73 (5): 751-754.

Hayashi, Naoki, and Saito Susumu. ed. 2010. Tettai no nouson keikaku [Land Use Reorganization]. Kyoto: Gakugei Shuppan-Sha.

ICOMOS. 1964. "International Charter for The Conservation and Restoration of Monuments and Sites." https:// www.icomos.org/charters/venice_e.pdf

ICOMOS. 1999. "The Nara Document on Authenticity." https://www.icomos.org/charters/nara-e.pdf

IPSI (Secretariat of the International Partnership for the Satoyama Initiative). "Satoyama, the Japanese Traditional Agricultural Landscape." Accessed 1 March 2019. https://satoyama-initiative.org/about/\#1.3

Irodori Cooperative. 2019. "Story of Irodori." Accessed February 26 2019. https://www.irodori.co.jp/own/ index.asp

Ishizawa, Maya. 2018. "Cultural Landscapes Link to Nature: Learning from Satoyama and Satoumi." Built Heritage 2 (4): 7-19.

Kuroda, Nobu. 2002. "Changes in Forest Uses and Their Influence on the Forest Landscape in Shirakawa-Mura, Ogimachi." Landscape Research Japan 65 (5): 659-664.

MAFF (Ministry of Agriculture, Forestry and Fisheries). 2015. "Multifunctional Roles of Agriculture, Forestry and Fisheries and Rural Areas." Accessed 15 February 2019. http://www.maff.go.jp/e/data/publish/attach/ pdf/maff_2016-2.pdf

Matsumoto, Kunihiko, Sakai Akifumi, and Sawaki
Masanori. 2017. "Landscape Management Community Organizations in the Conservation Systems after Designation of Important Cultural Landscapes." Landscape Research Japan 80 (5): 553-558.

MILT (Ministry of Land Infrastructure, Transport and Tourism). 2007. "Analysis of Current situation of hamlets for National and Regional Planning." Accessed 26 February 2019. http://www.mlit.go.jp/kisha/ kisha07/02/020817_.html

Nanto City. 2012. "Conservation Master Plan for Gokayama, Nanto City, World Heritage Site." Accessed 18 February 2019. https://www.city.nanto.toyama.jp/cmssypher/www/service/detail.jsp?id=9938

Nanto City 2017. "Basic Data of Population and Households.” 26 February 2019. https://www.city.nanto. toyama.jp/cms-sypher/www/secfolder/johoseisaku/ tokei_top.htm

Odagiri, Tokumi. 2017. Nousanson wa shoumetsu shinai [Farming and Mountain Villages will Not Disappear]. Toyko: Iwanami shinsho.

Ohno, Akira. 2008. Marginal Villages and Revitalization of Rural Area. Shizuoka Shimbun

Oku, Hirokazu, and Yumiko Murakami. 2011. Analysis of Utilization of Satoyama from Building Materials of a Traditional Farmhouse: History of Villages and Forests. Bun-ichi Sogo Shuppan.

OPNEOV (Organization for the Protection of the Natural Environment in Ogimachi Village), ed., 2011. History of Shirakwa-go Ogimachi for 40 Years. Shirakawa Mura Board of Education.

Otoshi, Masahiko. 1998. Village Revitalization by "Gokkun Umaji Mura". Nihon Keizai Shinbun sha (Nikkei).

Shirakawa Mura. 1994. "Preservation plan for ShirakawaMura Ogimachi Preservation District for Groups of Traditional Buildings."

Shirakawa Mura. 1998. New Edition: History of Shirakawa Village 3. Shirakawa Village.

Shirakawa Mura. 1999. "Preservation Rules for the Shirakawa-Mura Ogimachi Preservation District for Groups of Traditional Buildings."

Statistics Bureau. 2012. "Ministry of Internal Affairs and Communications, S Statistics of Japan, Chapter 2, 2-1 Transition and Estimate of Population." Accessed 26 February 2019. https://www.stat.go.jp/data/chouki/02. html

Statistics Bureau. 2018. Census of Agriculture and Forestry. https://www.e-stat.go.jp/stat-search/files?page $=1$ \&layout $=$ datalist $\&$ toukei $=00500209 \&$ tstat $=000001016$ $170 \&$ cycle $=0 \&$ tclass $1=000001112708 \&$ tclass $2=00000$ 
1112709\&cycle_facet $=$ tclass $1 \% 3$ Atclass $2 \&$ second $2=1$ (accessed 2019-02-26).

Taira Mura Board of Education. 1996. "Report of Conservation and Management Plan: Historic Site of Echu Gokayama Ainokura Village."

UNESCO (United Nations Educational, Scientific and Cultural Organization). 2015. "Policy Document for the Integration of a Sustainable Development Perspective into the Processes of the World Heritage Convention as adopted by the General Assembly of States Parties to the World Heritage Convention at Its 20th session."

Urry, John. 2002. The Tourist Gaze. 2nd ed. Thousand Oaks: Sage.

Working Group for Cultural Landscape. ed. 2016. Chiiki no mikata: Bunkatekikeikangaku no susume [How to Look at Regions: Introduction of Cultural Landscape Studies]. Nara: National Institutes for Cultural Heritage Nara National Research Institute for Cultural Properties. 